Original scientific paper

UDK: 340.134:355.02(327(4))

DOI: $10.5937 / j \mathrm{js} 16-29804$

Received: 9 December 2020 / Accepted: 16 March 2021

\title{
Deterioration of the Global Arms Control Regime and the Role of the Vienna Document in Reviving Stability and Confidence in Europe
}

\author{
ANDREJ STEFANOVIĆ* \\ University of Belgrade, Faculty of Political Science, Serbia \\ Ministry of Foreign Affairs of the Republic of Serbia, \\ Permanent Mission to the UN Office in Geneva**
}

\begin{abstract}
The author explores the deterioration and (forthcoming) collapse of the global arms control system, with special consideration given to potential consequences this event would have for the European continent. In this context, and in assessing the significance of the remaining mechanisms for preventing a potential arms race and deepening of conflict in Europe, he draws attention to the OSCE Vienna Document as a tool that could enable the revival of stability through confidence-building in Europe, especially given its capacity for adaptation and modernization.
\end{abstract}

Keywords: arms control, Vienna Document, OSCE, Europe, confidence-building

\section{Introduction}

The foundation of the global arms control system was constructed during the Cold War through direct engagement between the two superpowers, the United States (US) and the Soviet Union (USSR). The negotiations continued even after the end of the Cold War, this time between the US and the Russian Federation. The resulting arms control regime was set up to achieve strategic stability, chiefly through freezing stockpiles and limiting and reducing the number of deployed nuclear weapons, but also by prohibiting certain types of weapon systems. The negotiations were arduous and sometimes produced instruments that were scrapped only a few years later. Nevertheless, they proved to be instrumental in thwarting the two superpowers from engaging in direct armed conflict.

\footnotetext{
*andrejstef89@gmail.com

** The author of the article is a PhD Candidate at the University of Belgrade, Faculty of Political Science and Attaché at the Ministry of Foreign Affairs of the Republic of Serbia, currently serving in the Permanent Mission to the UN Office in Geneva. The views and opinions expressed in the article are those of the author and do not represent the official policy or position of the Ministry of Foreign Affairs of the Republic of Serbia.
} 
Recently, and most notably since the early 2000s, this global arms control system has been under threat due to the changing global order. There is a danger that the world could be brought back into the situation of the early days of the Cold War when there were no mutually set rules on arms control. This could easily lead to a new arms race and escalation of the conflict. Against this background, the European continent is the most in jeopardy, as sizeable conventional and nuclear forces and weapon systems are placed close one to another. Consequently, it is of vital importance to close the gap created by the deterioration and collapse of many arms control agreements and to come up with new solutions to emerging threats. The content of the solution does not have to be a novel comprehensive legally-binding arms control treaty but could be more modest, even with a provisional effect aimed at increasing confidence and transparency in Europe in the existing crisis.

\section{Development of the Global Arms Control Regime}

The global arms control regime was created during the Cold War, through the engagement, direct talks, and agreements between the two superpowers - the USA and the USSR. ${ }^{1}$ Arms control efforts played a crucial role in alleviating and mitigating tension and precluding the escalation of potential conflict. ${ }^{2}$ Moreover, they count among the most prevalent reasons why the Cold War never broke out into a "real war."

Arms control was introduced because unregulated deterrence relationships created a danger of instigating potentially untold risks. Since the 1960s and 1970s, a series of attempts at controlling and containing these risks were made (firstly concerning nuclear

\footnotetext{
1 Arms control is designed to regulate and manage the levels of arms so that a "balanced level" is attained, either by limiting the growth of stockpiles, committing to caps on the size of arsenals, or agreeing on reciprocal reductions. Arms control is usually conducted bilaterally between major powers and rivals, with a view of enhancing mutual security. Modern arms control came about as a "brainchild" of the Cold War, and more specifically, the strategic relations between the US and the USSR. Unlike arms control, disarmament aims at reducing or eliminating weapons or certain classes of weapons (predominately those which are deemed inhumane). A third concept, non-proliferation, has the objective of preventing the spread of certain (usually nuclear) weapons to countries that do not possess them (Finaud 2020).

There are departing views on the interplay between disarmament and arms control, as some take disarmament as a generic term which encompasses arms control and non-proliferation activities also (Casey-Maslen and Vestner 2019), while others argue that "arms control", which originally covered only rules on limiting arms competition, over time subsumed other measures, such as those usually associated with disarmament and non-proliferation (Goldblat 2002).

It is important to note that this article relates to arms control in its modern meaning, as activities, measures, and other forms of cooperation between the US and the Russian Federation, predominately in the nuclear sphere, but also when it comes to conventional weapons, which are aimed at providing predictability, transparency, and confidence, thus reducing tension and the probability of conflict, through limiting and reducing armament.
}

2 United Nations Office for Disarmament Affairs 2018, vii.

3 Ibid., 10; Kegley and Blanton 2010, 379. 
weapons, but later on, when it came to conventional weapons as well). ${ }^{4}$ The initial negotiations on arms control were triggered by the 1962 Cuban Crisis. They resulted in the 1963 "Hot Line Agreement", which established direct telegraph and radio communication links between the leaders of the two countries. It aimed to prevent tensions from spiraling and triggering the outbreak of a nuclear war. ${ }^{5}$ However, it was the Strategic Arms Limitation Talks (SALT) of the 1970s that laid down the principles upon which subsequent arms control negotiations were conducted, especially for achieving objectives of strategic stability, equal security, and equal limitation of weapons. ${ }^{6}$ The product of these Talks was the 1972 SALT I Interim Agreement, which envisaged a freeze, for five years, of the number of fixed land-based intercontinental ballistic missiles (ICBM) launchers and ballistic missile launchers on submarines. ${ }^{7}$ Simultaneously with this Agreement, the two parties adopted the Anti-Ballistic Missile (ABM) Treaty, which prohibited the deployment of ABM systems (albeit with certain exceptions). This Agreement was often referred to as "the cornerstone of strategic arms control", as it averted an arms race that would ensue had the two countries sought to improve their offensive strategic capabilities as a result of the effort to overcome the counterparts defence systems. Thus, the ABM Treaty provided a platform for negotiating limitations of offensive arms. ${ }^{8}$

With the Talks resuming a few years later, the two parties adopted the 1979 SALT II Agreement, which set the ceiling for ICBM launchers, submarine-launched ballistic missiles (SLBM), heavy bombers, and long-range air-to-surface ballistic missiles. Even though this agreement never entered into force, its terms were respected by the two countries until $1986 .{ }^{9}$ Despite its numerous shortcomings, such as the fact that the limitations ceiling was put too high, the real significance of SALT II could be found in the "promise of more meaningful nuclear arms limitation measures."10

Notwithstanding their great importance, the agreements reached in the framework of SALT foresaw constraints only on intercontinental and ballistic missiles. In doing so, they created a gap heavily exploited by the two superpowers, which produced and deployed many short and intermediate range missiles. ${ }^{11}$ This omission was addressed by the 1987 Intermediate Range Nuclear Forces (INF) Treaty, which became an institution in its own right. ${ }^{12}$ This Treaty led to the elimination of an entire category of weapons - nuclear and conventional ground-launched ballistic and cruise missiles with ranges between 500 and

4. OSCE Network of Think Tanks and Academic Institutions 2018, 14.

5 Kegley and Blanton 2010, 379; Arms Control Association 2020c.

6 Arms Control Association 2020.

7 Goldblat 2002, 80.

8 Ibid., 72; Casey-Maslen and Vestner 2019, 58.

9 Casey-Maslen and Vestner 2019, 56.

10 Casey-Maslen and Vestner 2019, 83.

11 Goldblat 2002, 84.

12 Nichols 2019. 
$5,500 \mathrm{~km}$. This meant that some of the most dangerous nuclear and conventional weapons were removed from the European continent. ${ }^{13}$ Because of this, the INF Treaty was considered an essential element of stability in Europe. ${ }^{14}$

Again, drawing attention in the negotiations to non-strategic nuclear weapons only created new opportunities for the two countries to increase their strategic nuclear arsenals. The nuclear warhead stockpiles of the US and the USSR reached their peaks in the late 1980s. To tackle this worrying trend, the Treaty on the Reduction and Limitation of Strategic Offensive Arms (START I) was adopted in 1991. Unlike the INF Treaty, START I did not anticipate the elimination of an entire weapon category. Rather, it obliged the two sides to execute substantive cutbacks in offensive nuclear arsenals. The START I introduced mutually comparable levels regarding the limitations of nuclear delivery vehicles and warheads and was strengthened by stringent verification measures. ${ }^{15}$ To complement the provisions of START I and to further enhance the reduction in nuclear arsenals, the US and the Russian Federation signed, two years later, the START II. Not only was this Treaty supposed to impose new ceilings on the deployment of nuclear weapons (lower compared to START I), but it also contained prohibitions of ICBMs carrying more than one nuclear warhead (Multiple Independently targeted Reentry Vehicles - MIRVs). However, this Treaty never entered into force. ${ }^{16}$

Despite the shock created by the US withdrawal from the ABM Treaty in 2002, during that same year, the two countries signed the Treaty on Strategic Offensive Reductions (SORT, or the so-called Moscow Treaty), aimed at lowering the danger of unauthorized or accidental nuclear war through the decrease of the number of nuclear warheads. In essence, the Treaty codified the unilateral commitments regarding nuclear arms reductions made during the preceding years. ${ }^{17}$ With this Treaty, the two countries affirmed their commitment to reinvigorating the strategic relationship between them. ${ }^{18}$

In time the SORT was superseded by the Treaty on Measures for the Further Reduction and Limitation of Strategic Offensive Arms (the New START), which introduced novel reductions on the deployment of nuclear strategic warheads by setting a cap at 1,550 nuclear warheads and bombs each. However, it did not regulate non-deployed ICBMs and SLBMs. ${ }^{19}$ The New START entered into force on 5 February 2011, originally for 10 years, but it was subsequently extended for five years (the longest period permitted by the treaty).

13 Casey-Maslen and Vestner 2019, 56, 59; Nichols 2019.

14 OSCE Network of Think Tanks and Academic Institutions 2018, 14.

15 Goldblat 2002, 87; Casey-Maslen and Vestner 2019, 56.

16 Goldblat 2002, 92-94.

17 Casey-Maslen and Vestner 2019, 56; Goldblat 2002, 96.

18 Goldblat 2002, 97.

19 Arms Control Association 2021.

14 


\section{Conventional Arms Control in Europe}

Unlike the nuclear sphere, which was slowly being regulated throughout the 1960s and 1970s, the conventional arms segment was left unchecked until the adoption of the Conventional Forces in Europe (CFE) Treaty in 1990. For a long time, there was an asymmetry in conventional military relations in Europe, as the USSR had the upper hand over the Western Block. ${ }^{20}$ Arms control measures were used to try and remedy this imbalance. However, the efforts made during the Cold War on reaching an agreement were unsuccessful. As the relations between the US and the USSR improved, and as the Cold War was drawing to a close, the negotiations on conventional armed forces on the European continent gained momentum and led to the adoption of the CFE Treaty. It became the first significant conventional arms control agreement to cover all of Europe, as it applied to the entire land territory of the states parties (member states of the NATO and the Warsaw Pact) "from the Atlantic Ocean to the Ural Mountains." ${ }^{21}$ It was termed the cornerstone of European security, ${ }^{22}$ as it created a military balance between the Western (NATO) and the Eastern Block (the Warsaw Pact) by reducing holdings in five major categories of conventional weapons - tanks, artillery pieces, armoured combat vehicles, combat aircraft, and attack helicopters ${ }^{23} \mathrm{On}$-site inspections were also prescribed by the Treaty provisions for verifying compliance. ${ }^{24}$

Over time, with the breakup of the USSR and the dissolution of the Warsaw Pact, the text of the Treaty was in danger of becoming obsolete. This triggered the negotiations for updating and adapting the Treaty. The negotiations resulted in the conclusion of the Agreement of the Adaption of the CFE Treaty in 1999, which whipped out the block structure in the Treaty and introduced national ceilings of total equipment that can be stationed on national territories. ${ }^{25}$

The CFE Treaty was a significant step in safeguarding European security as it enforced partnership among different European states, ${ }^{26}$ while strategic stability was ensured through eliminating disparities in conventional forces in Europe ${ }^{27}$ Its goal was not only to disable participating states from launching surprise attacks, by prohibiting the concentration of forces but also to rule out the outbreak of a nuclear war, that could come about as a consequence of a conventional weapons conflict. ${ }^{28}$

20 Goldblat 2002, 69.

21 Goldblat 2002, 222.

22 Casey-Maslen and Vestner 2019, 57.

23 Ibid.; Ray and Kaarbo 2008, 266.

24 Goldblat 2002, 224.

25 Ibid., 227.

26 Ibid., 230.

27 Ibid.

28 Ibid.; Arms Control Association 2007. 
Besides the CFE Treaty, another pillar of the European arms control architecture was also drafted in the early 1990s - the 1992 Open Skies Treaty. This Treaty, on the one hand, enabled states parties to conduct observation flights over the territories of other states parties (referred to as the "active quota"), and, on the other hand, obliged state parties to accept a certain number of over-flights (called "passive quota"). These short-notice, unarmed reconnaissance flights were designed as specific confidence- and security-building measures because they allowed states parties to collect data on other states' military forces and activities. ${ }^{29}$ Together with the 1990 Vienna Document of the Organization for Security and Co-operation in Europe (OSCE), the CFE and the Open Skies Treaty constituted a web of interlocking and mutually reinforcing obligations and commitments, ${ }^{30}$ and have been considered parts of the European comprehensive arms control framework. ${ }^{31}$

\section{Deterioration and Collapse of Conventional and Nuclear Arms Control System}

After decades of toil and commitment that were put into creating a global arms control regime, the overwhelming sentiment is that in the latest period, the world has been heading in the opposite direction, given the rise of new geopolitical tensions. ${ }^{32}$ Geopolitical changes have led to the unravelling of the global arms control architecture, which is manifested through the persistent blockade of negotiating new arms control instruments, as well as the violations and abandoning of existing arms control instruments. Moreover, it is claimed that this disentanglement of the arms control system is a signal that we are witnessing a transition to new international order (in a sense, a "new Cold War"). The only difference being that this time the international order will be deprived of rules on arms control, which have proven to be pivotal in preventing major power conflict. ${ }^{33}$

The first "victim" of the emergence of new geopolitical challenges and international tensions was the CFE Treaty. Due to mutual allegations concerning non-compliance, NATO members first refused to ratify the 1999 Adapted CFE Treaty. The Russian Federation went a step further in 2007 as it suspended the implementation of the original 1990 CFE Treaty. NATO members followed suit, and in 2011 declared the termination of their fulfilment of CFE Treaty obligations in relation to Russia. ${ }^{34}$ Even though the CFE Treaty is still formally in force, nevertheless the downscaling of obligations and the effective limitations of the scope of application have resulted in its decline. There are also risks that the Open Skies Treaty may meet a similar fate. The US officially withdrew from the Treaty

29 Nuclear Threat Initiative, n.d.; Arms Control Association 2020a; Casey-Maslen and Vestner 2019, 60.

30 Organization for Security and Co-operation in Europe (OSCE), n.d.

31 Schmitt 2018, 271.

32 Tannenwald 2018.

33 Lodgaard, n.d.

34. Casey-Maslen and Vestner 2019, 58. 
in November 2020, after announcing beforehand their intention to leave the Treaty, due to alleged Russian violations of treaty obligations. ${ }^{35}$ After this, Russian officials required other participating states to issue a legally binding confirmation that they would not share with the US information acquired through flights over the Russian territory, nor that they would decline Russian flights over US military bases in Europe. ${ }^{36}$ As the Europeans failed to concur with this demand, Russia announced in mid-January 2021 that it would be setting into motion required procedural mechanisms for withdrawal from the Open Skies Treaty. Hence, the Treaty's demise looks probable. ${ }^{37}$

On the side of nuclear arms control, the first shock came in 2002 with the US withdrawal from the ABM Treaty. The American officials claimed that the Treaty was signed in a "vastly different world" 38 and that it restrained the US from developing systems to counter missile attacks launched by terrorists and "rogue states".39 Accordingly, this important parcel in the puzzle of international security and the cornerstone of strategic stability ${ }^{40}$ was taken out of the equation, and this contributed to further deterioration of the arms control system. Indeed, the collapse of this Treaty marked the start of a new arms race, albeit a qualitative, rather than a quantitative one, as it focused more on new technologies and capabilities. ${ }^{41}$

These developments were seen by Russia as a mistake and a new call for an arms race. ${ }^{42}$ Russia soon ceased its participation within the "Nunn-Lugar Cooperative Threat Reduction Program", which was kicked off by the US during the final months of the Cold War, to assist Russian in safeguarding its fissile material. Russia also boycotted the 2016 Nuclear Security Summit, which was held in Washington. ${ }^{43}$

Another step towards the dismantlement of the global arms control system occurred in 2019, with the US withdrawal from the INF Treaty. The INF Treaty was also considered a pillar of US-Russia (USSR) arms control relations, but it was also thought of as an "invaluable break on nuclear war." ${ }^{44}$ With its removal, the world could be faced with an even energized arms race, which would involve not only strategic but also tactical nuclear weapons, as well as conventional arms. ${ }^{45}$

35 U.S. Department of State, n.d.; Voice of America 2020.

36 Arms Control Association 2020b.

37 Baklitskiy and Radchenko 2021.

38 Neilan 2001.

39 Casey-Maslen and Vestner 2019, 58.

40 Ivanov 2000.

41 Tannenwald 2018.

42 TASS Russian News Agency 2018.

43 Tannenwald 2018.

44 Reuters 2019.

45 Arbatov 2019. 
All in all, the New START has become the only remaining arms control agreement remaining. As previously mentioned, the Treaty was extended in February 2021 and will be in force until 2026. However, the problem with the New START is the fact that it was intended to be a simple instrument, concluded to save the faltering arms control architecture, and pave the way toward a more comprehensive arms control agreement, which would include all the issues the New START does not regulate, such as tactical nuclear weapons, missile defence, air-launched missiles, as well as (most recently) hypersonic glide missiles. ${ }^{46}$ The US administration argues that the extension of the New START is not the end of the story, but is rather the beginning of future negotiations on a whole set of nuclear challenges, threats, and issues. ${ }^{47}$ In this sense, the extension of the New START will not resolve any challenges but can only buy time for sorting out outstanding issues. ${ }^{48}$ It is important to keep in mind that, if the two parties failed to negotiate a new treaty during the past ten years, there is even less probability that they would be successful this time around, with an even shorter deadline, particularly because of the dismal state of US - Russia relations. Additionally, President Biden's proposals for "re-entering" other arms control agreements, such as the Open Skies Treaty, might also prove to be a lot more difficult than originally contemplated, as the consent of Congress would be needed (i.e. a two-thirds majority). It is hard to imagine that many Republican Senators siding with Democrats to "re-join" a treaty the Republican administration had previously left. ${ }^{49}$

46 Sokov 2020.

47 Radio Free Europe Radio Liberty 2021; U.S. Department of State 2021.

Both the US and Russia have shown interest lately in introducing other powers to nuclear arms control negotiations, with a contrary request being made by the US (which insists on China's involvement) and Russia (which argues that the existing framework should be extended to other nuclear states, foremost the UK and France). Despite the claim that the international order has been multipolarized after the end of the Cold War, nonetheless, such changes have so far not affected the global arms control regime, which has never become multipolar. The US and Russia still account for more than $90 \%$ of the total global nuclear weapons, even after all of the reductions that have been conducted in line with obligations set out in the New START, and other arms control agreements (as well as unilateral reductions). This renders the continuation of bilateral negotiations on arms control necessary, at least for the time being. Other countries that possess nuclear weapons are lagging far behind, as their nuclear arsenals are considerably smaller (for instance, China's nuclear arsenal is less than one-tenth of the US or Russian one). If the US continues to insist that China joins the negotiating table on reducing nuclear forces, it is likely that this will require substantial confidence-building and transparency, as the US cannot simply coerce China into joining the arms control arena (China has thus far rejected even considering these calls). Even though a comprehensive arms control agreement on restricting nuclear weapons with China would be virtually impossible at this stage, there are nevertheless still untapped areas for engaging China in potential negotiations, such as defensive strategic systems, outer space systems, and tactical nuclear weapons.

48 Sokov 2018.

49 Air Force Magazine 2020. 


\section{Confidence Building and Stability in Europe: The Role of the Vienna Document}

The US and Russia are in a state of strategic instability, an extent to which not seen since the end of the Cuban Crisis (or, at least, since the end of the Cold War), which means that an accident, error, or miscalculation might trigger (nuclear) war. ${ }^{50}$ Despite this, the two countries still share an existential interest in preventing the use of nuclear weapons. ${ }^{51}$ That being said, reviving strategic stability is a long-term process, and the overall political climate is not conducive to negotiating a new arms control agreement. At the same time, it is clear that action must be taken immediately on countering the dangers posed by the degrading arms control system for the European continent. ${ }^{52}$ Europe is in a particularly sensitive situation, as there are no mutually agreed rules governing conventional forces on the continent after the collapse of the CFE Treaty. Means of establishing, maintaining, and enhancing predictability, transparency, and confidence are slowly fading out, with the expected disappearance of the Open Skies Treaty. There is a real danger of a new "Euromissile crisis", similar to the one from the beginning of the 1980s, because of the collapse of the INF Treaty..$^{53}$ All the while both the US and Russia have, for a long time, been deploying hundreds of tactical nuclear missiles on the continent. This situation is additionally fueled by the existence of US missile defence sites in Poland and Romania, which RF sees as a threat to its strategic deterrence potential. ${ }^{54}$

The recent history and downturn in arms control treaty-making, as well as the collapse of the already existing ones, leads one to believe that arms control treaties are coming to an end. To paraphrase Kenneth Adelman's observations from his 1984 Foreign Affairs article, at first glance, the problem is clear - no nuclear arms control agreement has been concluded in more than a decade, and both Washington and Moscow have produced scant evidence that a new agreement can be concluded anytime soon..$^{55}$ Furthermore, Schelling's diagnosis from 1985 of what went wrong with arms control - that what has recently been called arms control negotiations has mostly been a public exchanges of accusations ${ }^{56}-$ is still relevant today. Nonetheless, the end-goal of arms control remains - the preservation of strategic stability and prevention of (nuclear) war. ${ }^{57}$ This is why it is worth considering the option of reverting from treaty-making to other instruments, namely those of a soft law or political nature. Unlike "hard" arms control agreements, which deal with regulating or reducing the size and composition of weapons, soft arms control addresses misconceptions, concerns, and distrust, and aims at providing confidence regarding military inten-

50 Moniz and Nunn 2019.

51 Moniz and Nunn 2020.

52 Moniz and Nunn 2019; Sokov 2018.

53 Sokov 2020.

54 Baklitskiy, Bidgood, and Meier 2020.

55 Adelman 1984.

56 Schelling 1985.

57 Brooks 2020, 86. 
tions, with the ultimate goal of stabilizing relations between main actors. ${ }^{58}$ Therefore, the primary objective of these instruments does not have to be reductions, which was often the subject matter of arms control treaties, but rather they could be bent toward establishing parity, introducing predictability, and transparency, with the ultimate aim of ensuring stability. ${ }^{59}$

Having in mind that it would be more practical to build up on top of those regimes that are still operational and effective, and also that the importance of confidence- and security-building measures should be at the forefront of possible solutions, the OSCE's Vienna Document (VD) presents itself as a "prime suspect", as it is the only pillar of the European arms control architecture, previously mentioned, that still appears to be operational. In the context of the erosion of the arms control architecture and the overall growing security and military concerns in Europe, the Vienna Document has certainly found new relevance. ${ }^{60}$

The VD, designated as the most important OSCE confidence- and security-building instrument, ${ }^{61}$ was adopted in 1990 and amended several times afterward (in 1992, 1994, and 1999), with the latest version being adopted in 2011. The Vienna Document covers the goals set out in the 1975 Helsinki Final Act principles of confidence- and securitybuilding measures, which were later on elaborated in the 1986 Stockholm Document. ${ }^{62}$

The VD is designed to increase openness and transparency concerning military activities conducted inside the OSCE's zone of application, which includes the territory, territorial waters, and air space of European and Central Asian states (Russia from the western border to the Ural Mountains).$^{63}$ It requires participating states to share information on their respective military forces, military equipment, and defense planning. Apart from information exchange, the Vienna Document also contains provisions envisaging inspections and evaluation visits. ${ }^{64}$ The core philosophy behind the Vienna Document is boosting security through an increase in military transparency, which in turn reduces the element of surprise and the risk of miscalculation and misperception. ${ }^{65}$

The VD appears as a "living document" that is modified in correspondence with the changing security needs in Europe. This is evident from the four adaptations of the VD. Due to its soft law nature, it would be easier for parties to agree on novelties rather than in

58 Lachowski 2004, 1.

59 Ibid., 90.

60 Organization for Security and Co-operation in Europe (OSCE), n.d.1, 4.

61 Casey-Maslen and Vestner 2019, 60.

62 Arms Control Association, n.d.

63 U.S. Department of State 2021.

64 Organization for Security and Co-operation in Europe (OSCE), n.d.1, 4.

65 Schmitt 2018, 270. 
the case of a legally binding instrument. On the other hand, territorial limitations of these measures only to the European continent would make it possible for the US and Russia to come to terms and reach an understanding which would lead to greater stability in Europe while being in the position of pursuing their respective interests in other parts of world, something which has hampered reaching an agreement in the past.

However, to remain an effective tool, it needs to go through a process of modernization, above all in terms of extending its scope. It requires considerable strengthening and tightening, which necessitates greater willingness on the part of participating states to accept more intrusive measures, a greater degree of inspections, and observations, and provide more detailed information. ${ }^{66}$ In this sense, the inclusion of naval, coastal, air, air defence, and internal security forces into its scope of application should be carried out, as well as missile defense systems, and ballistic and cruise missiles. ${ }^{67}$ Other segments of the Vienna Document could also be reviewed, such as the lowering of the threshold for notification and observations. ${ }^{68}$

Keeping in mind that conventional and nuclear deterrence postures are increasingly intertwined in Europe, arms control efforts at some point have to have a nuclear component as well. ${ }^{69}$ Even though the Vienna Document is a conventional weapons instrument, nevertheless it could prove useful for addressing the most pertinent elements and aspects of nuclear challenges in Europe as well, especially those which have been previously managed by some of the agreements which have meanwhile ceased to exist. ${ }^{70}$ For example, unlike the INF Treaty, which envisaged scrapping of all US and Russian delivery systems of the intermediate range category, provisions could be introduced on reaching an understanding on the non-deployment of such systems in Europe. Likewise, new adaptations could cover missile defence systems, which are already seen as impeding strategic stability. If their complete removal is impossible, then there could be provisions on confidencebuilding to ensure that interceptors would not be directed against the Russian territory and its missiles, or prohibiting their installation in particularly sensitive zones. ${ }^{71}$ The two sides could explore pursuing new confidence-building measures through a reciprocal basis, where, for example, Russian concerns regarding US missile defense systems in Poland and Romania would be addressed in turn for enhancing predictability and transparency

66 Williams and Lunn 2020, 2.

67 Watson 2020, 10.

68 OSCE Network of Think Tanks and Academic Institutions 2018.

69 Kühn 2018, 8.

70 It would not be the first time that there is an expansion of the purview of the confidence- and security-building measures in Europe, such as the VD: unlike the traditional confidence-building measures of the late 1980s and early 1990s that mostly addressed the threat of a mass scale conventional military attack, new measures that emerged later on dealt with new threats and pertained to applying norms and standards of behavior and conduct that were previously not subject to review and scrutiny.

71 Williams and Lunn 2020, 7. 
about Russian tactical weapons in Europe. ${ }^{72}$ It is true that if confidence-building measures are to have any real effect a form of differentiation, including asymmetrical measures, is desired. In other words, the side which has the advantage should be constrained to a greater degree. These kinds of measures would have a countering effect on destabilizing tendencies that drive potential military confrontation. The willingness to do so would mark a significant step forward toward modernization of the VD, as well as overall arms control and confidence-building in Europe. ${ }^{73}$

In reality, glitches in the process of modernizing the Vienna Document do exist, as a few years ago Russians were in favour, and the US against, with the roles being switched recently. However, it is important to point out that in principle, there is understanding and support for such a feat and that there is only an issue of timing, i.e., ensuring the convergence of the two countries' positions at the same point in time. Likewise, if different positions keep the two sides from reaching a deal on a comprehensive update of the VD, they could make use of its article X (which encourages participating states to conclude additional bilateral or regional agreements) to conjure up bilateral VD-compatible confidence- and security-building measures. After all, the US and Russia bear a special responsibility in the drafting and implementing updates of the VD, because of their military capabilities, build-ups, and since their security approaches contribute to the growing insecurity and distrust in Europe. ${ }^{74}$

\section{Conclusion}

We are witnessing the collapse of global arms control. Unlike the building of the arms control regime, which took a couple of decades, the collapse of this system appears to be happening in a "time-lapse", with the demolition of many treaties and perspective crumbing of others happening in a matter of years. This has not come out of the blue, but on account of worsening power relations, the emergence of a new international order, and the general lack of confidence and transparency. Special attention must be given to Europe, which would be most hit by the voidance of rules on nuclear and conventional arms control.

Having in mind the experience of constructing arms control agreements, it is evident that there is not sufficient time to repeat these accomplishments. At the same time, the collapse of these agreements, and the increase in instability and likelihood of a new arms race, indicate that a solution needs to be found as soon as possible. To fulfil the overriding objective of avoidance of further deterioration, which might lead to more destabilization and even conflict, but at the same time aiming at reaching the solution quickly, the attention is turned to already existing political arms control agreements, which are durable,

72 Kühn 2018, 8.

73 Williams and Lunn 2020, 6.

74. Ibid., 9. 
and yet flexible enough, and which could be employed as a transitional fix to the problem at hand. In the case of Europe, the potential of the Vienna Document is clear, as the most important OSCE confidence- and security-building instrument. Even though it has gained newly found relevance, nevertheless it is evident that it needs to be adapted to new emerging challenges. This adaption is with concern, mostly, to its scope of application. In other words, the Vienna Document ought to take over many aspects of conventional and nuclear arms control, which were once regulated by other arms control agreements. 


\section{References}

Adelman, Kenneth L. 1984. "Arms Control: Arms Control with and Without Agreements." Foreign Affairs 62: 240.

Air Force Magazine. 2020. “The US is Out of the Open Skies Treaty: What's Next?" November 23. Accessed December 9, 2020. https://www.airforcemag.com/the-us-isout-of-the-open-skies-treaty-whats-next/.

Arbatov, Alexey. 2019. "A New Era of Arms Control: Myths, Realities and Options." Carnegie Moscow Center. October 24. Accessed December 8, 2020. https://carnegie. ru/commentary/80172.

Arms Control Association. 2020. "Russia's View on Nuclear Arms Control: An Interview with Ambassador Anatoly Antonov." April 2020. Accessed December 8, 2020. https://www.armscontrol.org/act/2020-04/interviews/russias-view-nucleararms-control-interview-ambassador-anatoly-antonov.

Arms Control Association. 2020a. “The Open Skies Treaty at a Glance." November 2020. Accessed December 8, 2020. https://www.armscontrol.org/factsheets/ openskies\#: :text=Signed\%20March\%2024\%2C\%201992\%2C\%20the,on\%20 military\%20forces\%20and\%20activities.

Arms Control Association. 2020b. "U.S. Completes Opens Skies Treaty Withdrawal." Accessed December 9, 2020. https://www.armscontrol.org/act/2020-12/news/uscompletes-open-skies-treaty-withdrawal.

Arms Control Association. 2020c. "Hotline Agreements." May 2020. Accessed December 8, 2020. https://www.armscontrol.org/factsheets/Hotlines.

Arms Control Association. 2021. “The New START at a glance." Accessed February 15, 2021. https://www.armscontrol.org/factsheets/NewSTART.

Arms Control Association. 2007. "The CFE Treaty and European Security." Accessed December 8, 2020. https://www.armscontrol.org/act/2007-12/issue-briefs/cfe-treatyeuropean-security.

Arms Control Association. n.d. "Vienna Document 1999." Accessed December 8, 2020. https://www.armscontrol.org/factsheets/ViennaDoc99.

Arms Control Association. n.d.1. "What if the New START Expires?" Accessed December 8, 2020. https://www.armscontrol.org/act/2020-01/features/what-if-newstart-expires-three-national-perspectives. 
Baklitskiy, Andrey and Radchenko, Sergey. 2021. "The Death of Open Skies Means a More Dangerous World." The National Interes. February 4. Accessed February 15, 2021. https://nationalinterest.org/blog/buzz/death-open-skies-means-moredangerous-world-177607.

Baklitskiy, Andrey, Bidgood, Sarah and Meier, Oliver. 2020. "Russia-U.S. Strategic Stability Talks: Where They Are and Where They Should Go." Deep Cuts Issue Brief \#13. October 30. Accessed December 8, 2020. https://deepcuts.org/news/ detail/page?tx_news_pi1\%5Bnews\%5D=222\&cHash=85b28119b066f6177807 9e3061350884.

Brooks, Linton F. 2020. “The End of Arms Control.” Daedalus, the Journal of American Academy of Arts and Sciences 159 (2): 84-100.

Casey-Maslen, Stuart, and Tobias Vestner. 2019. A Guide to International Disarmament Law. New York: Routledge.

Finaud, Marc. 2020. "Multilateralism and Arms Control: The End of an Era?" Geneva Centre for Security Policy. October 16. Accessed December 8, 2020. https://www. gcsp.ch/global-insights/onlytogether-multilateralism-and-arms-control-end-era.

Goldblat, Jozef. 2002. Arms Control: The New Guide to Negotiations and Agreements. London: SAGE Publications.

Graef, Alexander (@alxgraef). 2020. "US No Longer Party to the \#Openskiestreaty. If Russia Continues to Insist on Written, Legally Binding Assurances, the Treaty Will Fail." Twitter. November 22. Accessed December 8, 2020. https://twitter.com/ alxgraef/status/1330511205052592128.

Gricius, Gabriella. 2020. "US-Russia relations in 2020: The End of Effective Arms Control?" European Leadership Network. Accessed December 8, 2020. https://www. europeanleadershipnetwork.org/commentary/us-russia-relations-in-2020-the-endof-effective-arms-control/.

Ivanov, Igor. 2000. “The Missile-Defense Mistake: Undermining Strategic Stability and the ABM Treaty." Foreign Affairs. September/October. Accessed December 8, 2020. https://www.foreignaffairs.com/articles/2000-09-01/missile-defense-mistakeundermining-strategic-stability-and-abm-treaty.

Kegley, Charles W., and Shannon L. Blanton. 2010. World Politics: Trend and Transformation, 2010-2011 Edition. Boston: Cengage Learning. 
Kühn, Ulrich. 2020. "Back to the Future? The New Missile Crisis." In The INF Treaty of 1987: A Reappraisal, edited by Philipp Gassert, Tim Geiger, and Hermann Wentker, 355-368. Göttingen: Vandenhoeck \& Ruprecht GmbH \& Co.

Lachowski, Zdzislaw. 2004. Confidence-and Security-Building Measures in the new Europe: SIPRI research report No. 18. Oxford: Oxford University Press.

Lodgaard, Sverre. n.d. "International Order, Arms Control and Disarmament." United Nations Institute for Disarmament Research (UNIDIR). Accessed December 8, 2020. https://www.unidir.org/node/5557.

Moniz, Ernest J., and Sam Nunn. 2019. “The Return of Doomsday: The New Nuclear Arms Race - and How Washington and Moscow can stop it." Foreign Affairs. September/October. https://www.foreignaffairs.com/articles/russianfederation/2019-08-06/return-doomsday.

Moniz, Ernest J., and Sam Nunn. 2020. "Sleepwalking Toward the Nuclear Precipice." Foreign Affairs. December 15. Accessed February 15, 2021. https://www. foreignaffairs.com/articles/united-states/2020-12-15/sleepwalking-toward-nuclearprecipice.

Nichols, Tom. 2019. "Mourning in the INF Treaty" Foreign Affairs. March 4. Accessed December 8, 2020. https://www.foreignaffairs.com/articles/2019-03-04/ mourning-inf-treaty.

Neilan, Terence. 2001. "Bush Pulls Out of ABM Treaty; Putin Calls Move a Mistake." The New York Times. December 13. Accessed December 8, 2020. https://www. nytimes.com/2001/12/13/international/bush-pulls-out-of-abm-treaty-putin-callsmove-a-mistake.html.

Nuclear Threat Initiative. n.d. "Treaty on Open Skies." Accessed December 8, 2020. https://www.nti.org/learn/treaties-and-regimes/treaty-on-open-skies/.

Nünlist, Christian. 2018. "The OSCE's Military Pillar: The Swiss FSC Chairmanship." CSS Analyses in Security Policy, No. 237. Zürich: Center for Security Studies.

Organization for Security and Co-operation in Europe (OSCE). n.d. "Arms Control". Accessed December 8, 2020. https://www.osce.org/arms-control.

Organization for Security and Co-operation in Europe (OSCE). n.d.1. OSCE Forum for Security and Co-operation: Dialogue, Transparency, Confidence Building. Accessed December 8, 2020. https://www.osce.org/files/f/documents/5/a/77535_1. pdf. 
OSCE Network of Think Tanks and Academic Institutions. 2018. Reducing the Risks of Conventional Deterrence in Europe: Arms Control in the NATO-Russia Contact Zones. Vienna.

Politico. 2021. "Russia withdraws from Open Skies Treaty after U.S. departure." Last modified: February 14, 2021. Accessed February 14, 2021. https://www.politico.com/ news/2021/01/15/russia-open-skies-treaty-459597.

Radio Free Europe/Radio Liberty 2021. "Putin Signs Bill Extending New START Nuclear Arms-Control Treaty." January 19. Accessed February 14, 2021. https:// www.rferl.org/a/putin-signs-bill-extending-new-start-nuclear-arms-controltreaty/31076662.html.

Ray, James Lee, and Juliet Kaarbo. 2008. Global Politics. Boston: Houghton Mifflin Company.

Reuters. 2019. "U.N. Chief Says World Will Lose Brake on Nuclear War with End of INF Treaty." August 1. Accessed December 8, 2020. https://www.reuters.com/article/ us-russia-usa-missiles-un-idUSKCN1UR597.

Schelling, Thomas C. 1985. "What Went Wrong with Arms Control?" Foreign Affairs 64 (2): 214-233.

Schmitt, Olivier. 2018. "The Vienna Document and the Russian Challenge to the European Security Architecture." In Military Exercises: Political Messagning and Strategic Impact, edited by Beatrice Heuser, Tormod Heier and Guillaume Lasconjarias, 269-284. Rome: NATO Defence College.

Sokov, Nikolai (@SokovNikolai). 2020. “Since Russia Needs to Ratify New START Extension, May Make Sense to Start Ratification Process Early so That Only Last Vote is Scheduled for After Jan 20." Twitter. November 8. Accessed December 8, 2020. https://twitter.com/SokovNikolai/status/1325417632049340417.

Sokov, Nikolai. 2018. "New START Expires in 3 Years. And Nobody Knows Why." The National Interest. February 6. https://nationalinterest.org/feature/new-startexpires-3-years-nobody-knows-what-comes-next-24379.

Tannenwald, Nina. 2018. “The Vanishing Nuclear Taboo?” Foreign Affairs. November/December. Accessed December 8, 2020. https://www.foreignaffairs.com/ articles/world/2018-10-15/vanishing-nuclear-taboo.

TASS Russian News Agency. 2018. "Putin Says Race Between US, Russia Followed Washington's Withdrawal from ABM Treaty." March 2. Accessed June 28, 2020. https://tass.com/politics/992402. 
U.S. Department of State. 2021. "On the Extension of the New START Treaty with the Russian Federation." February 3. Accessed February 14, 2021. https://www.state. gov/on-the-extension-of-the-new-start-treaty-with-the-russian-federation/.

U.S. Department of State. n.d. "On the Treaty on Open Skies." Accessed December 8, 2020. https://www.state.gov/on-the-treaty-on-open-skies/.

United Nations Office for Disarmament Affairs. 2018. "Securing our Common Future: An Agenda for Disarmament”. Accessed December 8, 2020. https:// digitallibrary.un.org/record/1628227.

Voice of America. 2020, "US Officially Withdraws from Open Skies Agreement." November 22. Accessed December 8, 2020. https://www.voanews.com/usa/usofficially-withdraws-open-skies-agreement.

Watson, Eloise N. 2020. Strenghtening Conventional Arms Control in Europe: Small Steps to Overcome Big Hurdles. Fondation pour law Recherche Strategique.

Williams, Nicholas and Lunn, Simon. 2020. Modernising Conventional Arms Control: An Urgent Imperative. London: European Leadership Network. 